\title{
PENGARUH MODEL OUTDOOR STUDY TERHADAP KETERAMPILAN MENULIS PUISI PADA MATA PELAJARAN BAHASA INDONESIA DI KELAS V SD NEGERI 023905 BINJAI UTARA TAHUN AJARAN 2018/2019
}

\author{
OLEH: \\ HASNI SUCIAWATI \\ (PGSD UNIVERSITAS QUALITY MEDAN)
}

\begin{abstract}
The problem in this study is the students' writing essay writing skills that have not been maximized. One of the contributing factors is the learning model used is not in accordance with the learning material. The purpose of this study was to find out the implementation of Indonesian language learning by using Outdoor Study learning model and conventional methods learning in Writing Essay rhymes. The study was conducted at SDN 023905 Public Elementary School in Binjai utara on juli , 2019. The population of this study was all fifth grade students of SDN 023905 Binjai Utara, which numbered 64 people and at the same time became research samples divided into two parallel classes. Data collection tool used tests and data analysis consisting of testing hypotheses using the two average difference test. From the data analysis obtained the description essay writing skills of students using Outdoor Study model learning gained an average of 80.85 and the conventional learning method gained an average of 70.70. From the two data it can be concluded that the Writing Skills Writing rhymes on the Outdoor Study Learning method is better than using the Conventional method in class V SDN 023905 Binjai Utara Academic Year 2019/2020.
\end{abstract}

\section{Keywords: Student Writing Skills, Outdoor Study Learning, Conventional Method Learning.}

\section{PENDAHULUAN}

Bahasa Indonesia merupakan mata pelajaran yang membelajarkan siswa untuk berkomunikasi dengan baik dan benar. Komunikasi ini dapat dilakukan baik secara lisan maupun tulisan. Dengan kesimpulan tersebut, maka standar kompetensi mata pelajaran bahasa Indonesia merupakan kualifikasi kemampuan minimal siswa yang menggambarkan penugasan, pengetahuan, keterampilan bahasa, sikap positif terhadap bahasa dan sastra Indonesia. Standar kompetensi ini merupakan dasar bagi siswa untuk memahami dan merespon situasi lokal, regional, nasional, dan global. 
Menulis merupakan suatu keterampilan berbahasa yang dipergunakan untuk berkomunikasi secara tidak langsung, tidak secara tatap muka dengan orang lain. Dalam kegiatan ini seorang penulis haruslah terampil memanfaatkan grafologi, struktur bahasa dan kosakata. Keterampilan menulis ini tidak akan datang secara otomatis melainkan harus melalui latihan dan praktik yang banyak dan teratur (Tarigan, 1994:3). Menulis juga merupakan segenap rangkaian kegiatan seseorang untuk mengungkapkan buah pikirannya melalui bahasa tulis untuk dibaca dan dimengerti oleh orang lain. Buah pikirannya itu dapat berupa pengalaman, pendapat, pengetahuan, keinginan, perasaan sampai gejolak hati seseorang.

Pengembangan keterampilan menulis, terutama yang berhubungan dengan karya sastra seperti puisi perlu mendapat perhatian yang serius karena menulis puisi tidak dapat terbentuk secara otomatis dan tidak semudah yang siswa bayangkan, siswa dituntut untuk pandai bermain kata-kata dan banyak memiliki referensi kata sehingga dapat menghasilkan sebuah puisi yang indah dan menarik untuk dibaca.

Dengan demikian, pengembangan keterampilan menulis puisi akan melatih keterampilan dan kreativitas siswa dalam mengekspresikan ide-ide dan kecerdasan dalam mengolah kata-kata. Berdasarkan hasil informasi yang diperoleh dari guru kelas V SDN 023905 Binjai Utara, menemukan banyak permasalahan yang muncul terkait dengan pembelajaran Bahasa Indonesia tersebut Pembelajaran menulis puisi yang dilaksanakan di sekolah tidak dimaksudkan untuk mencetak sastrawan, namun pembelajaran menulis puisi ini dimaksudkan untuk melatih siswa supaya terbiasa mengembangkan kemampuan mereke untuk menulis kreatif dalam hal ini menulis puisi.

Hal yang menyebabkan pembelajaran menulis kurang dikembangkan oleh guru dalam proses pembelajaran di kelas adalah kurangnya pengalaman guru dalam penulisan kreatif serta minimnya model-model pembelajaran dalam praktik menulis puisi

a. Dari fakta tersebut diketahui bahwa kemampuan siswa dalam menulis masih rendah. dan belum memenuhi tuntutan kriteria ketuntasan minimal (KKM) 
yang telah ditetapkan dengan angka 65. Salah satu solusi alternatif yang diambil adalah dengan menerapkan model pembelajaran Outdoor Study. Model ini merupakan upaya untuk mengatasi masalah kemandirian anak dengan memberikan kesempatan bermain sambil belajar. Adelia Vera (2016 : 16) menyatakan bahwa "Metode Outdoor Study merupakan metode pembelajaran kegiatan belajar mengajar antara guru dan murid, namun tidak dilakukan dalam kelas, tetapi dilakukan luar kelas atau alam terbuka, sebagai kegiatan pembelajaran siswa". Kelebihan Outdoor Study

1. Model pembelajaran Outdoor Study dapat mendorong motivasi belajar siswa.

2. Dalam pembelajaran Outdoor Study lebih mudah menciptakan suasana pembelajaran yang menyenangkan bagi para siswa.

3. Model pembelajaran Outdoor Study merupakan mampu mengasah aktivitas fisik dan kreativitas para siswa.

4. Di model pembelajaran Outdoor Study siswa menggunakan media pembelajaran yang konkret dan memahami lingkungan yang ada di sekitarnya.

5. Model pembelajaran Outdoor Study siswa tidak mudah lupa terhadap semua yang mereka pelajari di luar kelas.

6. Mendekatkan hubungan emosional antara guru dengan siswa, hubungan ini layaknya sebuah persahabatan yang akrab antara orang tua dan anak, yang berjalan dengan harmonis.

b. Kekurangan Outdoor Study

Disamping memiliki kelebihan, model pembelajaran Outdoor Study jugamemiliki kekurangan antara lain:

1. Para siswa bisa keluyuran kemana-mana karena berada di luar kelas.

2. Gangguan konsentrasi siswa, karena di luar kelas para siswa bisa terlena bermain serta muncul suara kebisingan.

3. Kurang tepat waktu, sebab para siswa dapat saja meremehkan berangkat ke lokasi belajar di luar kelas.

4. Pengelolaan kelas lebih sulit dilakukan dalam belajar di luar kelas. 
5. Lebih banyak menguasai praktik dan minim teori.

6. Bisa terserang panas dan dingin, karena tersengat sinar matahari atau angin sehingga para siswa merasa kedingin bila musim hujan.

\section{METODE PENELITIAN}

Penelitian ini dilaksanakan di SDN 023905 Binjai Utara pada semester genap Tahun Ajaran 2019/2020. Alasan peneliti memilih lokasi ini karena kemampuan menulis karangan deskripsi siswa belum maksimal. Populasi adalah keseluruhan subjek penelitian. Juliansyah Noor (2015 : 147) menyatakan bahwa "Populasi adalah digunakan untuk menyebut seluruh elemen/anggota dari suatu wilayah yang menjadi sasaran penelitian atau merupakan keseluruhan (universum) dari objek penelitian".

Sampel merupakan bagian dari populasi, yang diperoleh dengan cara pengacakan. Juliansyah Noor (2015 : 147) menyatakan bahwa "Sampel adalah sejumlah anggota yang dipilih dari populasi. Dapat disimpulkan bahwa sampel adalah sebagian dari populasi yang akan diteliti. Sampel penelitian ini diambil sebanyak 2 kelas, 2 kelas tersebut sama-sama merupakan kelas V. Pengambilan kelas pertama ditetapkan sebagai eksperimen yang diberi perlakuan model pembelajaran Outdoor Studydan kedua kelas diberi perlakuan metode pembelajaran konvensional.

Populasi dan sampel dalam penelitian ini yaitu seluruh siswa SDN 023905 Binjai Utara Tahun Ajaran 2019/2020 sebanyak 2 kelas dengan jumlah siswa 64 orang.

Tabel 3.1 Sebaran Anggota Populasi Dan Sampel

\begin{tabular}{|c|c|c|c|}
\hline No & Perlakuan Mengajar & Kelas & Jumlah Siswa \\
\hline 1 & Eksperimen & V $-\mathrm{A}$ & 32 orang \\
\hline 2 & Kontrol & V $-\mathrm{B}$ & 32 orang \\
\hline \multicolumn{2}{|c|}{ Jumlah } & 64 Orang \\
\hline
\end{tabular}

\section{Sumber : Guru kelas V SDN 023905 Binjai Utara}

Penelitian ini menggunakan metode quasi eksperimen dimana tidak memungkinkan peneliti untuk mengontrol semua variabel yang relevan kecuali 
dari beberapa variabel-variabel tersebut. Peneliti akan membagi menjadi dua kelompok, yaitu satu kelas eksperimen dan satu kelas kontrol.

Penelitian ini menggunakan rancangan penelitian control group pretestpretest desaing. Satu kelompok esksperimen di beri perlakuan dengan model pembelajaran Outdoor Study, sedangkan kelompok kontrol diberi perlakuan dengan metode pembelajaran konvensional. Test awal dilakukan untuk mengetahui sejauh mana materi atau bahan ajar yang akan diajarkan telah dikuasai oleh siswa, sedangkan test akhir dilaksanakan dengan tujuan untuk mengetahui apakah materi pelajaran sudah dapat dikuasai oleh siswa. Desain penelitian ini dapat digambarkan sebagai berikut:

Tabel 3.2 Rancangan Penelitian

\begin{tabular}{|c|c|c|c|}
\hline Perlakuan & Tes awal & Variabel & Tes akhir \\
\hline $\begin{array}{c}\text { Model Pembelajaran } \\
\text { Outdoor Study }\end{array}$ & $T_{1}$ & $\mathrm{X}_{1}$ & $T_{2}$ \\
\hline Pembelajaran Konvensional & $T_{1}$ & $\mathrm{X}_{2}$ & $T_{2}$ \\
\hline
\end{tabular}

\section{Keterangan:}

$T_{1}$ : Tes awal

$T_{2}:$ Tes akhir

$\mathrm{X}_{1}$ :Kemampuan siswa dengan menggunakan model pembelajaran Outdoor Study

$\mathrm{X}_{2}$ : Kemampuan siswa dengan menggunakan pembelajaran konvensional untuk mendapat data, dilakukan penelitian yang bersifat eksperimen. Agar kedua kelas homogen, maka proses penelitian ini dilaksanakan melalui tahap berikut:

1. Kedua kelas diberi tes awal

2. Kedua kelas diberi materi yang sama

3. Lama penyampaian materi harus sama

4. Guru yang menyampaikan materi adalah guru yang sama, peneliti sendiri.

5. Perbedaan hanya terletak pada perlakuan yaitu pembelajaran dengan model Outdoor Study dan pembelajaran dengan metode konvesional. 
6. Teknik analisis data yang digunakan yaitu pelaksanaan pembelajaran, ketuntasan belajar, perhitungan rata-rata, dan pengujian hipotesis.

\section{HASIL PENELITIAN DAN PEMBAHASAN}

Penelitian ini dilaksanakan di SDN 023905 Binjai Utara Tahun Ajaran 2019/2020 semester genap di kelas V A dan kelas V B yang jumlah siswa sebanyak 64 orang. Kelas menggunakan model pembelajaran Outdoor Study dan kelas menggunakan metode Konvensional. Sebelum peneliti melaksanakan proses pembelajaran maka terlebih dahulu dilakukan pre test untuk kedua kelas.

Dari analisis hasil pre test menunjukkan bahwa kemampuan awal antara siswa kelas V A dan siswa kelas V B tidak ada perbedaan secara signifikan. Hal ini dapat dilihat dari hasil nilai rata-rata pre test kedua kelas dan dibuktikan dengan t sampel bebas dua arah untuk melihat persamaan dua rata-rata. Dari hasil perhitungan diperoleh nilai rata-rata nilai kelas V A yaitu 43,22 dan rata-rata nilai kelas V B yaitu 43,88. Oleh karena itu, keputusan yang diambil adalah $H_{o}$ diterima artinya tidak terdapat perbedaan kemampuan awal antara kelas V A dan kelas V B. Dalam hal ini sangat memungkinkan karena kedua kelas tersebut belum diberi perlakuan.

Setelah pre test dilakukan maka peneliti melaksanakan proses pembelajaran. Di kelas proses pembelajaran dilakukan dengan model Outdoor Study dan di kelas menggunakan metode Konvensional. Untuk mengetahui apakah ada pengaruh model Outdoor Study terhadap keterampilan menulis karangan deskripsi maka dilakukan pos test untuk kedua kelas. Hasil nilai ratarata kelas ekperimen yaitu dan 80,85 nilai rata-rata kelas kontrol yaitu 70,70. Hasil data pos test kelas Outdoor Study dan Konvensional di uji kenormalannya dengan menggunakan uji normalitas data dan uji homogenitas varians. Setelah di uji, data pos test di dua kelas yaitu kelas eksperimen dan kelas kontrol berdistribusi normal dan homogen maka dapat di lanjutkan dengan pengujian hipotesis menggunakan rumus uji indenpenden antara dua faktor. Setelah dilakukan uji independen antara dua faktor di kedua kelas maka, di peroleh data pos test kelas Outdoor Study dan Konvensional yaitu $\mathrm{x}^{2}=7,21>\mathrm{x}_{(0,95)(2)}=6,89$ 
karena $\chi^{2}{ }_{\text {hitung }}>\chi^{2}{ }_{\text {tabel }}$ maka $\mathrm{H}_{0}$ ditolak dan $\mathrm{H}_{1}$ diterima. maka dapat disimpulkan bahwa dengan menggunakan model pembelajaran Outdoor Study ada pengaruh terhadap keterampilan menulis puisi pada mata pelajaran Bahasa Indonesia di kelas V di SDN 023905 Binjai Utara Tahun Ajaran 2019/2020.

Berdasarkan uraian di atas, maka dapat dikatakan bahwa model pembelajaran Outdoor Study berpengaruh terhadap keterampilan menulis puisi. Hal tersebut dikarenakan bahwa dalam model pembelajaran Outdoor Study siswa di berikan kesempatan untuk lebih aktif dan dalam pembelajaran ini dapat melibatkan siswa pada saat belajar mengajar berlangsung didalam kelas dan siswa juga tidak cepat merasa bosan karena dalam model pembelajaran Outdoor Study siswa dapat bermain sambil belajar. hasil penelitian ini menunjukkan bahwa model pembelajaran Outdoor Study lebih dapat meningkatkan hasil belajar siswa karena dengan model ini, siswa lebih memahami materi yang dipelajarinya.

\section{PENUTUP}

\section{Simpulan}

Berdasarkan hasil penelitian dan analisis data yang dilaksanakan di SDN 023905 Binjai Utara Tahun Ajaran 2019/2020 maka, dapat disimpulkan bahwa:

1. Keterampilan menulis puisi dengan menggunakan model Outdoor Study pada siswa kelas V SDN 023905 Binjai Utara Tahun Ajaran 2019/2020 diperoleh nilai rata-rata 80,85 .

2. Keterampilan menulis puisi dengan menggunakan metode Konvensional pada siswa kelas V SDN 023905 Binjai Utara Tahun Ajaran 2019/2020 diperoleh nilai rata-rata 70,70 .

3. Ada pengaruh yang signifikan metode Outdoor Study terhadap keterampilan menulis puisi pada mata pelajaran Bahasa Indonesia di kelas V SDN 023905 Binjai Utara Tahun Ajaran 2019/2020.

\section{Saran}

Berdasarkan simpulan maka peneliti memberikan beberapa saran sebagai berikut: 
1. Bagi Kepala Sekolah, sebagai sarana dalam memperluas wawasan dan pengetahuan terutama dalam rangka memperbaiki pembelajaran sehingga dapat meningkatkan mutu pendidikan.

2. Bagi Guru, untuk meningkatkan keterampilan menulis puisi sebaiknya menggunakan pembelajaran model Outdoor Study dari pada menggunakan metode Konvensional.

3. Bagi Siswa, pembelajaran model Outdoor Study dapat dijadikan salah satu alternatif untuk meningkatkan keterampilan siswa dalam pembelajaran Bahasa Indonesia dalam materi menulis puisi.

\section{DAFTAR PUSTAKA}

Sudjana. 2005. Metode Statistika, Bandung: Tarsito.

Suharsimi Arikunto,2013. Prosedur Penelitian Suatu Pendekatan Praktik.Jakarta: PT. Rineke Cipta.

Sugiyono. 2017. Metode Penelitian Pendidikan Kuantitatif, kualitatif dan $R \& D$, Bandung : Alfabeta.

Ahmad Susanto. 2016. Teori Belajar dan Pembelajaran. Jakarta: Prenada Media Group.

Hamruni. 2013. Strategi Pembelajaran. Yogyakarta: Insan Madani.

Purwanto. 2014. Evaluasi Hasil Belajar. Yogyakarta: Pustaka PelajarSardiman. 2014 .Interaksi \& Motivasi Belajar Mengajar. Jakarta: Rajawali Pers.

Slameto. 2013. Belajar dan Faktor-Faktor yang Mempengaruhi. Jakarta: Rineka Cipta.

Suharsimi Arikunto. 2015. Penilitian Tindakan Kelas. Jakarta: Bumi Aksara.

Sudjana .2013.Penilaian Hasil Proses Belajar Mengajar. Bandung: PT. Remaja Rosda karya.

Tampubolon. 2008. Kemampuan Membaca. Bandung: Angkasa Bandung.

Tampubolon Saur. 2014. Penelitian Tindakan Kelas. Jakarta: Penerbit Erlangga.

Trianto.2010. Mendesain Model Pembelajaran Inovatif-Progresif.Jakarta: Kencana Prenada Media Group.

Wina Sanjaya. 2010. Strategi Pembelajaran. Bandung: Kencana Prenada Media Group. 
Zainal Aqib, dkk. 2011. Penelitian Tindakan Kelas. Bandung: CV. Rama Widya.

Bubun Sihabul Millah, dalam http://alsyihab.blogspot.com/2010/10/penerapanstrategi-pq4r-preview.html. Akses Rabu, 21 Desember 2016.

Soelaiman, dalam http:// info dan pengertian.blogspot.co.id/2015/04/ pengertiankemampuan-ability-menurut.html. Akses Rabu, 21 Desember 2016. 